\title{
Analysis of Adult Autism Spectrum Disorders Screening Using Neural Network
}

\author{
Ridan Nurfalah \\ STMIK Nusa Mandiri \\ Jakarta, Indonesia \\ ridan.rlh@nusamandiri.ac.id
}

\author{
Sri Rahayu \\ STMIK Nusa Mandiri \\ Jakarta, Indonesia \\ srirahayu.rry@nusamandiri.ac.id
}

\author{
Muhammad Faittullah Akbar \\ Universitas Bina Sarana Informatika \\ Karawang, Indonesia \\ muhammad.mtl@bsi.ac.id
}

\begin{abstract}
One of the increasing developmental disorders in Indonesia is Autism Spectrum Disorder (ASD), developmental disorder characterized by difficulties to conduct verbal and non-verbal communication and social interaction. This disorder cannot be tolerated and requires early treatment to reduce its development. However, ASD treatments required ineffective treatment costs and waiting times diagnosis were lengthly. One effective alternative diagnosis isto use the screening technology to determine the early symptoms of ASD disorders. The rapid development of the number of ASD cases around the world required researchers to determine a dataset with behavioral properties to update the screening process. Thus, the purpose of this study is to predict the success of screening performed on adults with Autism Spectrum Disorder (ASD) using the researchers' results dataset, so that the dataset could be used as a benchmark for the success of the ASD screening process. The method used is machine learning neural network method with 100 training cycle, learning rate 0,01 and momentum 0,9 resulted in a classification accuracy of $96.00 \%$
\end{abstract}

Keywords-Autism Spectrum Disorder; Screening ASD; Machine Learning; Neural Network;

\section{INTRODUCTION}

One of the increasing developmental disorders in Indonesia is Autism Spectrum Disorder (Danuatmaja, 2003) in [1]. Autism Spectrum Disorder (ASD) is developmental disorder characterized by difficulties to conduct verbal and non-verbal communication and social interaction. (Ratnawati, 2003)

Increased intestinal mucosal permeability known as leaky gut is one of the key theories in the causes of Autism Spectrum Disorder (ASD). The primary cause of metabolic disorders in ASD is a weakened immune system. One of the immune system disorders that is often obtained in patients with ASD is to identify the cell itself as a foreign body cell, causing inflammatory reactions in the gastrointestinal tract. (Valentia, Sani, \& Anggreany, 2017)
The danger of this disorder, needs to be known early on, so it could be minimized or controlled, at least the family and the closest people can give more attention to ASD sufferers either young or adult. Today's technology is increasingly sophisticated and even reliable to predict various conditions so it can solve a problem by simply doing research and finding a pattern. This prediction could be done with a Neural Network classification data mining technique, the aim of this study is to predict screening conducted for Autism Spectrum Disorder (ASD) sufferers in.

A similar study had previously been conducted by Candra Agustina using the same dataset, using the Naive Bayes classification method with an accuracy value of $92.91 \%$. (Agustina, 2017)

Ferawati in her research solved a case of misdiagnosis of Autism sufferers by comparing the 
Chilhood Autism Rating Scale (CARS) method to the Support Vector Machine (SVM) method with accuracy rates of $90.49 \%$ and $90.89 \%$, respectively. (Ferawati, 2016)

Agus Subekti's predictive Autistic Spectrum Disorder modeling has also been done by comparing the decision tree method C. 45 with Naive Bayes, and it turns out that the C.45 algorithm is superior. (Farhan \& Subekti, 2018).

\section{Literature REVIEW}

Neural networks consist of two or more layers, although most networks consist of three layers: the input layer, the hidden layer, and the output layer (Larose, 2005) in (Badrul, 2013).

The neural network approach is motivated by biological neural networks. Roughly speaking, a neural network is a set of connected input / output units, where each connection has a weight associated with. Neural networks have several properties that make them popular for clustering. First, neural networks are inherently parallel and distributed processing architectures. Second, neural networks learn by adjusting the interconnection weights with data, this allows neural networks to "normalize" patterns and act as feature (attribute) extractors for different groups. Third, neural networks process numeric vectors and require object patterns to be represented by quantitative features only. (Gorunecu, 2011) in (Badrul, 2013).

The principle of neural network training uses Backpropagation, to illustrate this algorithm that there are three layers of the Neural Network algorithm consisting of inputs and outputs. Where the input consists of two and only one output as shown in the picture below. (Sucipto, 2012).

\section{Weight Initialization}

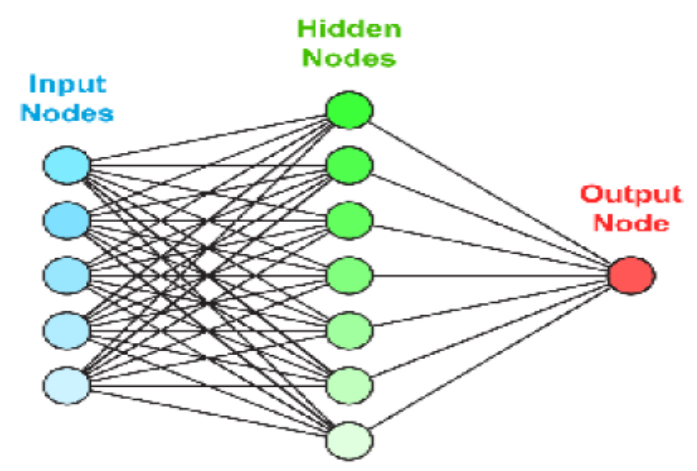

Source : (Sucipto, 2012)

\section{Figure 1. Neural Network Layer}

2. Each input (xji $i=1,2,3, \ldots, n)$ receive the signal from $\mathrm{x} 1$ input, then will be distributed to all hidden layer units.

3. Each hidden layer $\left(Z_{j i} j=1,2,3, \ldots, p\right)$ amount of the input signal weight.

$Z_{i n j}=W_{b j}+\sum_{i=1}^{n} x_{i} w_{j i}$

Source : (Sucipto, 2012)

4. Addition of the weight of the incoming signal to the output unit, using the activation function in calculating the output signal.

$y_{m}=w_{b o}+\sum_{j} w_{j o} z_{j}$

Source : (Sucipto, 2012)

5. Calculate information from errors

$\delta=(t-y) * f\left(y_{m}\right)$

Calculate the corrected weight (new wjo)

$A w_{j a}=\eta \delta z_{i}$

Source : (Sucipto, 2012)

Calculates the corrected bias

$A w_{h a}=\eta \delta$.

Source : (Sucipto, 2012)

6. Each unit from the Hidden $(\mathrm{Z} \pi \mathrm{J}=1,2, \ldots$, p) add up the input delta

$\delta_{\text {inj }}=\delta w_{j o}$

Source : (Sucipto, 2012)

To calculate the error multiplied by the activation derivative function

$\delta_{j}=\delta_{\text {inj }} f\left(z_{\text {inj }}\right) j$

Source : (Sucipto, 2012)

Weight Correction

$W_{j i}=\delta_{j} x_{i}$

Source : (Sucipto, 2012)

Bias correction

$w_{j o}($ new $)=w_{j o}($ old $)+\Delta w_{j o}$

Source : (Sucipto, 2012)

Each unit from the Hidden $(\mathrm{ZJ} 1 \mathrm{~J}=1,2,3$.., p) to update weights and biases

$w_{j i}($ new $)=w_{j i}($ old $)+\Delta w_{j i}$ 
Source : (Sucipto, 2012)

Iteration will be repeated until it gets the desired value.

Tabel 1. Setdata NN Process

\begin{tabular}{cccc}
\hline & X1 & X2 & $\mathrm{y} / \mathrm{z}$ \\
\hline 1 & 0 & 0 & 0 \\
\hline 2 & 1 & 0 & 1 \\
\hline 3 & 0 & 0 & 1 \\
\hline 4 & 1 & 1 & 1 \\
\hline
\end{tabular}

Source : (Sucipto, 2012)

The table above illustrates a set of data that can be used to teach neural network algorithms. The data set consists of input signals ( $\mathrm{x} 1$ and $\mathrm{x} 2$ ) that can be processed to achieve the desired target (output) $\mathrm{z}$, the neural network is an iterative process $(1,2,3,4)$ where in each iteration the weight coefficient is modified using new data from the training data set. Modifications enable to calculate using the algorithm described in the calculation example below.

Where the data in the table above consists of one input layer, with 2 neurons (i.e. Xi and X2) and the hidden layer, with 4 neurons (Z1, Z2, Z3 and Z4).

Sigmoid Activation:

$z=\frac{1}{1+e^{-Z} i n}$

Source : (Sucipto, 2012)

Sigmoid activation for 1 output layer with neuron

$y=\frac{1}{1+e^{y_{i n}}}$.

\section{Proposed Method}

This research was carried out with several steps including :

1. Determine the problem, the problem raised in this study is quite serious because it is related to interactions between humans, how they socialate and make new environment.

2. Dataset searching, the dataset that used is a classification type dataset, Autism-AdolescentData obtained from UCI Repository. Those are the detail of the dataset :

\section{Tabel II Atributes Features and their} descriptions

\begin{tabular}{|l|l|l|}
\hline Attribute & Type & Description \\
\hline Age & Number & Age in years \\
\hline Gender & String & Male or Female \\
\hline
\end{tabular}

\begin{tabular}{|c|c|c|}
\hline Ethnicity & String & $\begin{array}{l}\text { List of common } \\
\text { ethnicities in text format }\end{array}$ \\
\hline $\begin{array}{l}\text { Born with } \\
\text { jaundice }\end{array}$ & $\begin{array}{l}\text { Boolean (yes or } \\
\text { no) }\end{array}$ & $\begin{array}{l}\text { Whether the case was } \\
\text { born with jaundice }\end{array}$ \\
\hline $\begin{array}{l}\text { Family } \\
\text { member } \\
\text { with PDD }\end{array}$ & $\begin{array}{l}\text { Boolean (yes or } \\
\text { no) }\end{array}$ & $\begin{array}{l}\text { Whether any immediate } \\
\text { family member has a } \\
\text { PDD }\end{array}$ \\
\hline $\begin{array}{l}\text { Who is } \\
\text { completing } \\
\text { the test }\end{array}$ & String & $\begin{array}{l}\text { Parent, self, caregiver, } \\
\text { medical } \\
\text { clinician, etc. }\end{array}$ \\
\hline $\begin{array}{l}\text { Country of } \\
\text { residence }\end{array}$ & String & $\begin{array}{l}\text { List of countries in text } \\
\text { format }\end{array}$ \\
\hline $\begin{array}{l}\text { Used the } \\
\text { screening } \\
\text { app before }\end{array}$ & $\begin{array}{l}\text { Boolean (yes or } \\
\text { no) }\end{array}$ & $\begin{array}{l}\text { Whether the user has } \\
\text { used a screening app }\end{array}$ \\
\hline $\begin{array}{l}\text { Screening } \\
\text { Method } \\
\text { Type }\end{array}$ & $\begin{array}{l}\text { Integer } \\
(0,1,2,3)\end{array}$ & $\begin{array}{l}\text { The type of screening } \\
\text { methods chosen based } \\
\text { on age category } \\
\text { ( } 0=\text { toddler, } 1=\text { child, } 2= \\
\text { adolescent, } 3=\text { adult) }\end{array}$ \\
\hline $\begin{array}{l}\text { Question } 1 \\
\text { Answer }\end{array}$ & Binary $(0,1)$ & $\begin{array}{l}\text { The answer code of the } \\
\text { question based on the } \\
\text { screening method used }\end{array}$ \\
\hline $\begin{array}{l}\text { Question } 2 \\
\text { Answer }\end{array}$ & Binary $(0,1)$ & $\begin{array}{l}\text { The answer code of the } \\
\text { question based on the } \\
\text { screening method used }\end{array}$ \\
\hline $\begin{array}{l}\text { Question } 3 \\
\text { Answer }\end{array}$ & Binary $(0,1)$ & $\begin{array}{l}\text { The answer code of the } \\
\text { question based on the } \\
\text { screening method used }\end{array}$ \\
\hline $\begin{array}{l}\text { Question } 4 \\
\text { Answer }\end{array}$ & Binary $(0,1)$ & $\begin{array}{l}\text { The answer code of the } \\
\text { question based on the } \\
\text { screening method used }\end{array}$ \\
\hline $\begin{array}{l}\text { Question } 5 \\
\text { Answer }\end{array}$ & Binary $(0,1)$ & $\begin{array}{l}\text { The answer code of the } \\
\text { question based on the } \\
\text { screening method used }\end{array}$ \\
\hline $\begin{array}{l}\text { Question } 6 \\
\text { Answer }\end{array}$ & Binary $(0,1)$ & $\begin{array}{l}\text { The answer code of the } \\
\text { question based on the } \\
\text { screening method used }\end{array}$ \\
\hline $\begin{array}{l}\text { Question } 7 \\
\text { Answer }\end{array}$ & Binary $(0,1)$ & $\begin{array}{l}\text { The answer code of the } \\
\text { question based on the } \\
\text { screening method used }\end{array}$ \\
\hline $\begin{array}{l}\text { Question } 8 \\
\text { Answer }\end{array}$ & Binary $(0,1)$ & $\begin{array}{l}\text { The answer code of the } \\
\text { question based on the } \\
\text { screening method used }\end{array}$ \\
\hline $\begin{array}{l}\text { Question } 9 \\
\text { Answer }\end{array}$ & Binary $(0,1)$ & $\begin{array}{l}\text { The answer code of the } \\
\text { question based on the } \\
\text { screening method used }\end{array}$ \\
\hline $\begin{array}{l}\text { Question } \\
10 \text { Answer }\end{array}$ & Binary $(0,1)$ & $\begin{array}{l}\text { The answer code of the } \\
\text { question based on the } \\
\text { screening method used }\end{array}$ \\
\hline $\begin{array}{l}\text { Screening } \\
\text { Score }\end{array}$ & Integer & $\begin{array}{l}\text { The final score obtained } \\
\text { based on the scoring } \\
\text { algorithm of the } \\
\text { screening method used. } \\
\text { This was computed in an } \\
\text { automated manner }\end{array}$ \\
\hline
\end{tabular}

3. Literature study and review previous research that is similar and done before to make a comparison. There are three previous studies that became the literature.

4. Determine classification algorithm that has a good prediction level. This research using neural 
network algorithm apllied by Rapid Miner that produces an accuracy level called confusion matrix, mind to particularize the accuracy of the research method using neural network alghoritm.

5. Experiment in this research using Rapid Miner that include process of training, learning and testing using the Neural Network algorithm, 98 data datasets were processed. The dataset contains attributes age, gender, ethnicity, jundice, austim, contry_of_res, used_app_before, result, relation, and Class/ASD that has been done before the cleaning process.

6. Draw a conclusion from the data that has been processed with the highest accuracy value, confusion matrix, and area under the curve.

The following is a presentation of a research methodology chart :

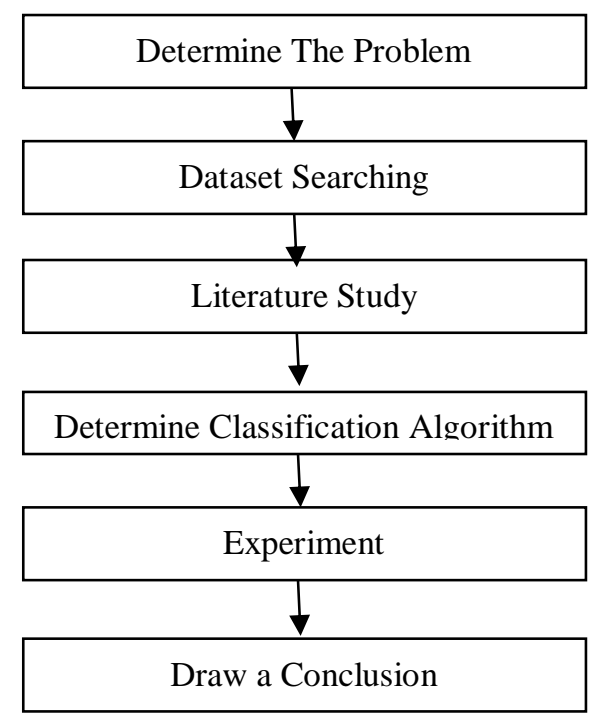

Figure 2. Research Method

Research method that proposed in this study is to process and calculate how deep Neural Network algorithm influence the method. The dataset initialized by the form of testing and learning data, the dataset is transformed into binominal type of range 0 and range 1 , then the dataset is divided into 10 -fold cross validation. The dataset was tested using Neural Network method to validate the model accuracy.

Area under the curve (AUC) became the evaluation model that apllied in this research. AUC became the indicator of the accuracy mean to evaluate the performance of the algorithm metod. Referring to Gorunescu in (Ridwansyah \& Purwaningsih, 2018) classification to test the accuracy of using AUC is formulated in the following range $0.90-1.00$ (Excellent Classification), $0.80 \quad-0.90$ (Good Classification), 0.70 - 0.80 (Fair Classification), 0.60 - 0.70 (Poor Classification), 0.50 - 0.60 (Failure).

\section{RESUlt AND DISCUSSION}

The data that is processed and analyzed is a dataset obtained from the UCI Repository using a neural network algorithm with a total of 98 data processed. The results of the analysis will determine the neural network algorithm model can provide influence and high accuracy in determining whether people have detected an autism spectrum disorder.

\section{Neural Network}

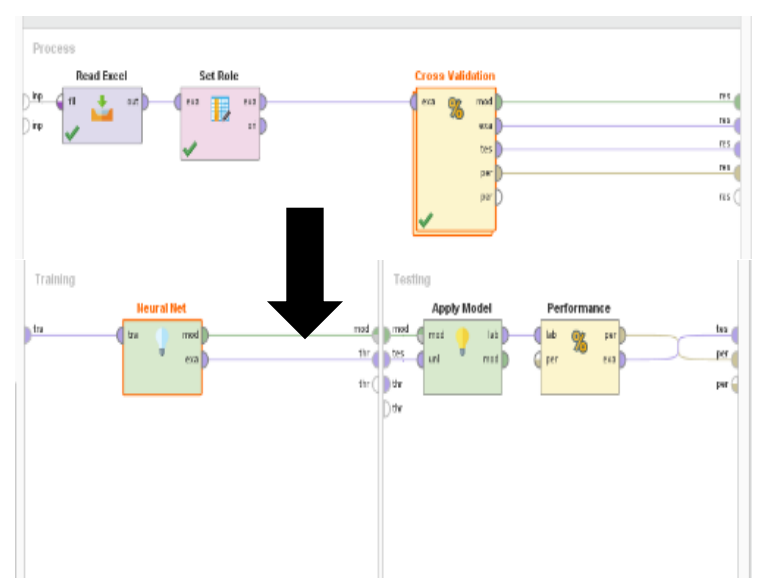

Figure 3 : Testing of Neural Network

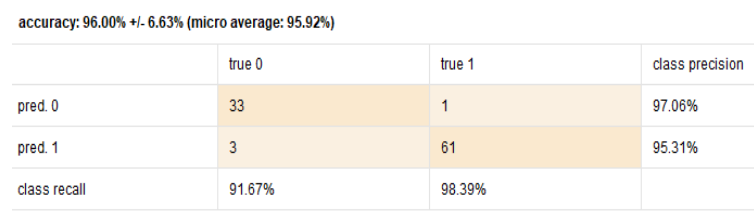

Figure 4 : Value of Accyracy Data Training Model Neural Network

$$
\begin{aligned}
\text { Accuracy } & =\frac{(\mathrm{TN}+\mathrm{TP})}{(\mathrm{TN}+\mathrm{FN}+\mathrm{TP}+\mathrm{FP})} \\
& =\frac{(61+33)}{(61+1+33+3)} \\
& =\frac{(94)}{(98)}
\end{aligned}
$$




$$
=0,9592=95,92 \%
$$

The testing training dataset Autism-AdolescentData using Neural Network algorithm models obtained 95,92\% accuracy referring to the result of confusion matrix that appeared in figure 4 contain 98 data. The data unveil the result that 33 data were predicted correctly that is classified as detected autism spectrum disorder classification, and the other data as many as 1 data predicted as detected autism spectrum disorder but it turned out to be undetected autism spectrum disorder classification. The other residual data consist 61 data were predicted to be exact that is classified as undetected autism spectrum disorder classification, and 3 data were predicted as udetected autism spectrum disorder classification but included in the class of the detected autism spectrum disorder classification as the confusion matrix table appeared in figure 4 .

The further test using Neural Network method that appearenced in figure 5 by consisting three layer. The first layer include of an input layer of 9 nodes such as age, gender, ethnicity, jundice, austim, contry_of_res, used_app_before, result, relation, and 1 node that became the bias node of the first layer. The second layer called with a hidden layer that consist 7 nodes with 1 bias node existed. The last layer is the the output layer that consist 2 nodes represent the class of the ASD which divide by two categories. The first node represent the detected autism spectrum disorder classification and the second one represent undetected autism spectrum disorder classification. The experiment of neural Network with three layers that consist 1 hidden layer appearenced in figure 5 .

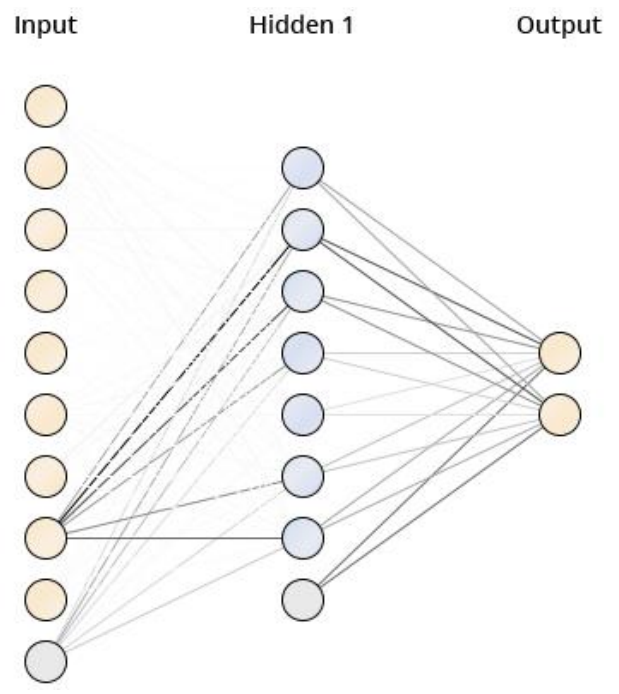

\section{Figure 5 : Neural Network Test Results Model with 7 nodes in hidden layer}

The results of ROC test that appearenced on the Area Under the Curve (AUC) data processing using the Neural Network algorithm produce a value of 0.990. This value indicates a high level of accuracy and can be categorized as very well result of the test presented in figure 6 .

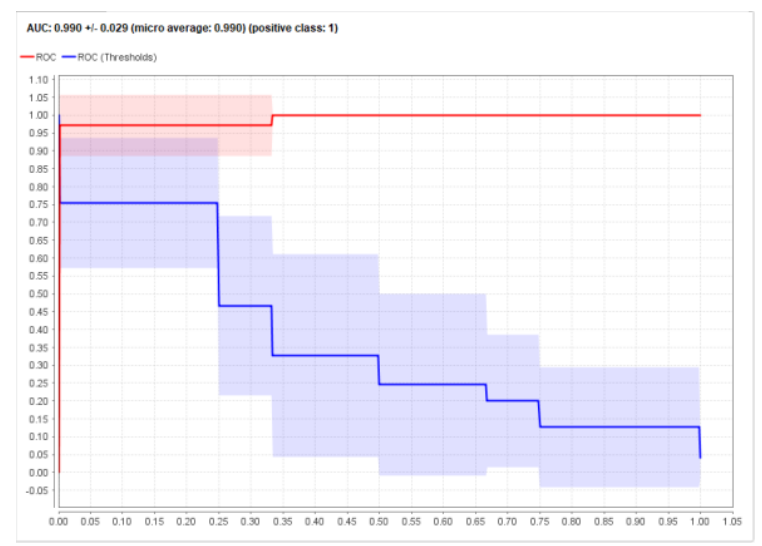

Figure 6 : AUC Neural Network

\section{Conclusion ANd Suggestion}

a. Conclusion

Based on experiments that have been conducted in this study with the Autism-Adolescent-Data dataset with the number of attributes that have been done cleaning 9 attributes that show behavioral parameters that support the success of the ASD screening process to find out an earlier diagnosis in people with ASD disorders. The study using machine learning neural network classification algorithm with 98 datasets, training cycle 100 , learning rate 0.03 and momentum 0.9 processed using the rapid miner tool turned out to produce a high accuracy value of $96.00 \%$ with an AUC of 0.990 . Based on these accuracy values can be categorized very well and show that the dataset can be one of the benchmarks in predicting an earlier diagnosis of people with ASD disorders with the ASD Screening process in adulthood.

b. Suggestion

This research can be further expanded by adding more features and algorithm for further research and analysist. Try to choose what method to use and can compare results with more varied and accurate methods. 


\section{REFERENCES}

Agustina, C. (2017). Optimasi Naive Bayes Menggunakan Particle Swarm Optimization Untuk Meningkatkan Akurasi Deteksi Autisme Spectrum Disorder. Journal SpeedSentra Penelitian Engineering Dan Edukasi, 10(2), 1-5.

Badrul, M. (2013). PREDIKSI HASIL PEMILU LEGISLATIF DKI JAKARTA DENGAN METODE NEURAL NETWORK BERBASIS PARTICLE SWARM OPTIMIZATION Pendahuluan. PREDIKSI HASIL PEMILU LEGISLATIF DKI JAKARTA DENGAN METODE NEURAL NETWORK BERBASIS PARTICLE SWARM OPTIMIZATION, IX(1), 37-47.

Farhan, O., \& Subekti, A. (2018). Permodelan Prediktif Autistic Spectrum Disorder Dengan Algoritma C.45. Jurnal Techno Nusa Mandiri, 15(2), 99. https://doi.org/10.33480/techno.v15i2.897

Ferawati. (2016). Analisis Akurasi dalam Identifikasi Autism dengan SVM. http://repositori.usu.ac.id/handle/123456789/ 1892.

Ratnawati, H. (2003). Leaky Gut sebagai Penyebab Gangguan Gastrointestinal pada ASD. Jurnal Kedokteran Maranatha, 2, 1-14.

Ridwansyah \& Purwaningsih, E. (2018). Particle Swarm Optimization Untuk Meningkatkan Akurasu Prediksi Pemasaran Bank. Jurnal PILAR Nusa Mandiri, 14(1), 83-88.

Sucipto, A. (2012). CREDIT PREDICTION WITH NEURAL NETWORK ALGORITHM Ir . Adi Sucipto , M. Kom . Sains and Technology Faculty Universitas Islam Nahdlatul Ulama Jepara. (15), 978-979.

Valentia, S., Sani, R., \& Anggreany, Y. (2017). Orangtua Pada Ibu Dari Anak Yang Terdiagnosis Autism Spectrum Disorder ( Asd ). 4(1), 43-58. 